Article

\title{
Weed Infestation and Health of Organically Grown Chamomile (Chamomilla recutita (L.) Rausch.) Depending on Selected Foliar Sprays and Row Spacing
}

\author{
Cezary A. Kwiatkowski ${ }^{D}$, Małgorzata Haliniarz and Elżbieta Harasim * (D) \\ Department of Herbology and Plant Cultivation Techniques, University of Life Sciences, Akademicka 13, \\ 20-950 Lublin, Poland; czarkw@poczta.onet.pl (C.A.K.); malgorzata.haliniarz@up.lublin.pl (M.H.) \\ * Correspondence: elzbieta.harasim@up.lublin.pl; Tel.: +48-81-4456820
}

Received: 22 April 2020; Accepted: 12 May 2020; Published: 13 May 2020

\begin{abstract}
Chamomile is a herbal plant of very high economic importance worldwide. Its organically grown raw material is particularly valuable. Under organic farming conditions, weeds and fungal diseases are an important problem in a chamomile plantation. Seeking agronomic solutions designed to eliminate the occurrence of these pathogens in chamomile crops is constantly valid. The aim of the present study was to evaluate the effect of some foliar sprays (enhancing the condition of the crop plant and its competition against pathogens) and different row spacing of two chamomile cultivars on weed infestation and health of a chamomile plantation. The study results presented in this paper were collected from field experiments carried out in the organic system in the village of Dys (the central Lublin region, Poland) over the period 2014-2016. Experiments were conducted on podzolic soil (class III) as a split-block design in 3 replicates in plots with an area of $525 \mathrm{~m}^{2}\left(6.25 \mathrm{~m}^{2}\right.$ a single plot). This study included two chamomile cultivars ("Złoty Łan", "Mastar"). The second experimental factor was single or double foliar application of three bioproducts (Herbagreen Basic, Bio-algeen, Effective Microorganisms-EM Farming). The other experimental factor was a different row spacing of chamomile $(40 \mathrm{~cm}$ and $30 \mathrm{~cm}$ ). The obtained study results show that 10-16 annual weed species and 1-3 perennial species occurred in both chamomile cultivars. Foliar application of the bioproducts contributed to a reduction in the total number of weeds in the crop, but at the same time to greater weed species diversity. In the control treatments (without the bioproducts), the dominance of several weed species (Viola arvensis, Galeopsis tetrahit, Spergula arvensis, Juncus bufonius, Scleranthus annuus) and lower biodiversity of the weed flora were observed. The largest reduction (by about 20\%) in the number of annual weeds was found under the influence of the bioproducts Herbagreen Basic and Bio-algeen applied once. Bio-algeen and Effective Microorganisms (EM), in turn, had a significant effect on decreasing the weed weight. A narrower $(30 \mathrm{~cm})$ row spacing of chamomile had a significant impact on reducing the weight of weeds in chamomile crops compared to the wider spacing, which was $40 \mathrm{~cm}$. It should be concluded that infection of the chamomile plantation with fungal diseases was overall at a low level. Significantly higher infection with fungal diseases was found in the case of the cultivar "Mastar", regardless of the experimental factors. A statistically proven decrease in infection of chamomile plants with fungal diseases was determined under lower crop density conditions (a row spacing of $40 \mathrm{~cm}$ ). Chamomile plants were found to exhibit better health under the influence of double application of the biofertilizers Herbagreen Basic and Bio-algeen.
\end{abstract}

Keywords: chamomile; organic system; bioproducts; seeding density; quantitative weed infestation indicators; weed species; fungal diseases 


\section{Introduction}

Chamomile (Chamomilla recutita (L.) Rausch.) is one of the most popular herbal plants grown in different countries across the world. The great economic importance of this herbal plant is due to the valuable chemical composition of chamomile raw material (flower heads) and its application in medicine, pharmacy, and cuisine [1,2]. Chamomile raw material obtained from organic plantations is particularly valuable. In organic cultivation where, by definition, no crop protection chemicals (herbicides, fungicides, insecticides) or synthetic mineral fertilizers are used, chamomile plants are more susceptible - than in conventional cropping - to weed pressure and infection with fungal diseases $[3,4]$. The negative effects of weed infestation on yield quantity and quality of crops are due to the high competitiveness of weeds for all environmental resources (light, water, nutrients, space) as well as their initial faster rate of growth and more effective use of $\mathrm{CO}_{2}$ [5-7]. Differences in the number and weight of weeds and in their biological diversity between the organic and conventional farming systems predominantly result from crop agronomy, which involves crop rotation, tillage and cropping technology, and weed control methods [8-10]. By depleting nutrients from the soil, weeds increase the susceptibility of crops to fungal diseases [11].

Seeking environmentally friendly agronomic solutions that enhance the resistance and competitiveness of herbal plants against weeds and pathogenic fungi is currently very popular. A proper selection of a chamomile variety as well as an appropriate seeding rate and density (the width of interrows in herbal crops), which will allow for natural competition with weeds, can be of major importance in this respect [3,12]. In science and agricultural practice, special hopes are associated with bioproducts (such as growth biostimulators, organic foliar fertilizers, Effective Microorganisms) which increase crop plant resistance to adverse habitat conditions and pathogens $[4,13,14]$.

This study hypothesized that foliar application of biological products in chamomile crops would contribute to better competitiveness of this crop plant against weeds and its higher resistance to fungal pathogens compared to the control treatment (without foliar application). An assumption was also made that the study would allow us to determine a species-specific optimal row spacing in the context of crop competition with pathogens. It was also hypothesized that the cultivar factor would not have a significant effect on weed infestation and health of chamomile.

The aim of the present study was to evaluate the effect of some foliar sprays: biostimulator, foliar fertilizer, Effective Microorganisms (enhancing the condition of the crop plant and its competition against pathogens), and different row spacing ( 30 and $40 \mathrm{~cm}$ ) of two chamomile cultivars ("Złoty Łan" and "Mastar") on weed infestation and health of a chamomile plantation.

\section{Methods}

Field experiments in growing chamomile (Chamomilla recutita (L.) Rausch.) were conducted in the

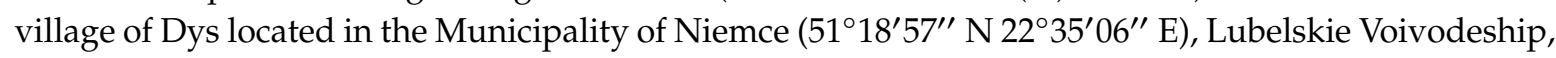
Poland, over the period 2014-2016. The experiment was set up as a split-block design with 3 replicates. The total experimental area was $525 \mathrm{~m}^{2}$. Treatments with the two chamomile cultivars were the experimental blocks. These blocks comprised alternately arranged plots with 2 different row spacings of chamomile. Seven foliar spray fertilization treatments were randomly assigned to these 2 chamomile cultivars and 2 row spacings of this herbal plant. The experiment included a total of 84 plots with a single plot area of $6.25 \mathrm{~m}^{2}$ (each plot was in the shape of a $2.5 \mathrm{~m} \times 2.5 \mathrm{~m}$ square). The characteristics analyzed in this study were determined in each of the 84 experimental plots. The specific design of this field experiment is shown in Figure 1. Chamomile was grown on a podzolic soil classified as very good rye soil complex (soil class II). Crops were grown in the experimental field in the organic farming system (without using synthetic mineral NPK fertilizers and without application of crop protection chemicals-herbicides, fungicides, and insecticides). 


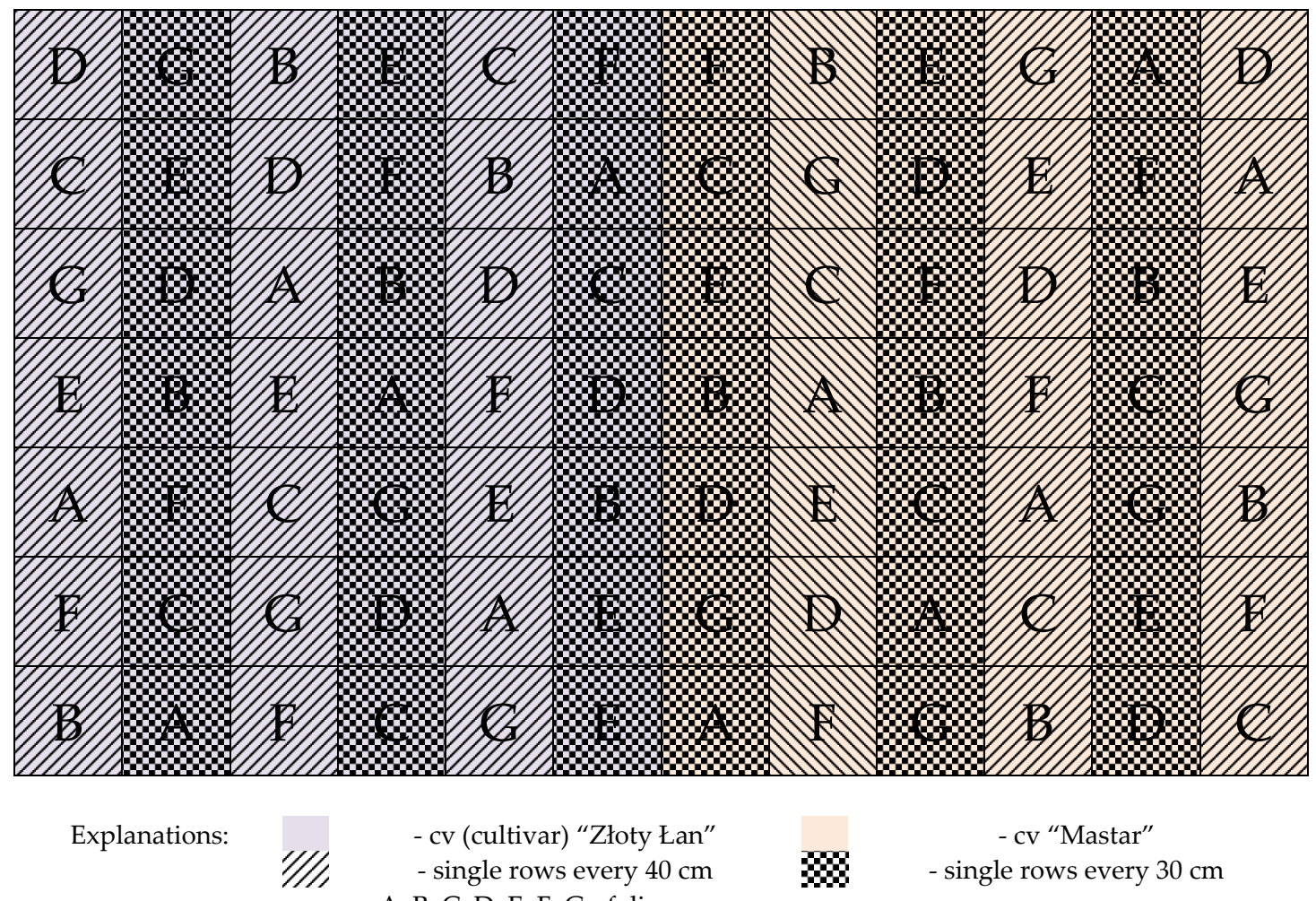

Figure 1. Design of the field experiment on the cultivation of chamomile.

In the field where the experiment was conducted, organic farming had been carried out since 2009 and thus for 5 years before the establishment of the experiment in question. During the period 2009-2013, the following crops were organically grown in this field: oats, potato, spring barley and white mustard. Throughout this entire period (2009-2016), this field was (and still is) under supervision of a certification body (Polish Society of Organic Farming "Eco-guarantee") and it has an Organic Farming Certificate. The experiment conducted in the organic system was surrounded by a $200-\mathrm{m}$ "buffer zone" (with organically grown lacy phacelia, red clover, and oats). The distance between the experimental plots and the nearest traffic artery was $700 \mathrm{~m}$.

During the study period, the soil was characterized by slightly acidic $\mathrm{pH}$ (in $1 \mathrm{M} \mathrm{KCl}=6.2-6.4$ ) and a medium content of available macronutrients $\left(\mathrm{P}=78.1-78.6 ; \mathrm{K}=84.9-86.1 ; \mathrm{Mg}=31.6-32.6 \mathrm{mg} \mathrm{kg}^{-1}\right)$. The soil humus content was $1.39-1.43 \%$.

In both experiments with the above-mentioned chamomile cultivars, the following factors were included:

I. Chamomile cultivars

a. "Złoty Łan" - a commonly grown cultivar;

b. "Mastar"- a new and less popular cultivar.

II. Foliar sprays:

A-Without application of foliar sprays (control treatment);

B-Foliar spray Herbagreen Basic-(10 g in $1.0 \mathrm{~L}$ of water);

C-Foliar spray Bio-algeen S90-(4.0 mL in $1.0 \mathrm{~L}$ of water);

D-Foliar spray Effective Microorganisms-EM Farming-(60.0 mL in $1.0 \mathrm{~L}$ of water);

E-Double application of the foliar spray Herbagreen Basic- $(2 \times 5 \mathrm{~g}$ in $1.0 \mathrm{~L}$ of water $)$;

F-Double application of the foliar spray Bio-algeen $\mathrm{S} 90-(2 \times 2.0 \mathrm{~mL}$ in $1.0 \mathrm{~L}$ of water);

G-Double application of the foliar spray Effective Microorganisms-EM Farming- $(2 \times 30.0 \mathrm{~mL}$ in $1.0 \mathrm{~L}$ of water).

III. Row spacing and seeding density: 
1. Single rows every $40 \mathrm{~cm}$;

2. Single rows every $30 \mathrm{~cm}$.

In each year of the study, white mustard grown for green manure was the previous crop for chamomile. Pre-sowing soil fertilization included a mineral fertilizer approved for use in organic farming-Humac Agro (Table 1.).

Table 1. Chemical composition of Humac Agro fertilizer.

\begin{tabular}{|c|c|c|c|c|c|c|c|c|}
\hline \multicolumn{9}{|c|}{ Nutrient Content on A Dry Weight Basis * } \\
\hline $\begin{array}{l}\text { Humic } \\
\text { acid \% }\end{array}$ & $\begin{array}{c}\mathrm{K} \\
\mathrm{g} \mathrm{kg}^{-1}\end{array}$ & $\begin{array}{c}\mathrm{Ca} \\
\mathrm{g} \mathrm{kg}^{-1} \\
\end{array}$ & $\begin{array}{c}\mathrm{Na} \\
\mathrm{g} \mathrm{kg}^{-1}\end{array}$ & $\begin{array}{c}\mathrm{Fe} \\
\mathrm{g} \mathrm{kg}^{-1}\end{array}$ & $\begin{array}{c}\mathrm{Zn} \\
\mathrm{mg} \mathrm{kg}^{-1}\end{array}$ & $\begin{array}{c}\mathrm{Br} \\
\mathrm{mg} \mathrm{kg}^{-1}\end{array}$ & $\begin{array}{c}\mathrm{Cu} \\
\mathrm{mg} \mathrm{kg}^{-1}\end{array}$ & $\begin{array}{c}\text { Se } \\
\mathrm{mg} \mathrm{kg}^{-1}\end{array}$ \\
\hline 62.0 & 1.18 & 16.80 & 12.80 & 14.50 & 64.0 & 77.0 & 19.0 & 6.0 \\
\hline
\end{tabular}

Chamomile seeds were sown directly into the soil in the third decade of April (using a hand seeder with a press wheel). The seeding rate was $2.0 \mathrm{~kg} \mathrm{ha}^{-1}$ (a row spacing of $40 \mathrm{~cm}$ ) $-2.5 \mathrm{~kg} \mathrm{ha}^{-1}$ (a row spacing of $30 \mathrm{~cm}$ ). Weed control involved mechanical weed removal (with a weeder) at the 3-5 leaf stage of chamomile. The foliar sprays (treatments B-G) were applied using a field sprayer under a pressure of $0.25 \mathrm{MPa}$. Double application was done at the 2-3 leaf stage of chamomile and at the 5-7 leaf stage (after mechanical weed removal). Single application of the sprays was carried out at the 5-7 leaf stage of chamomile. The specific composition of the bioproducts used in this experiment is shown in Table 2.

Table 2. Components of the sprays used in the experiment.

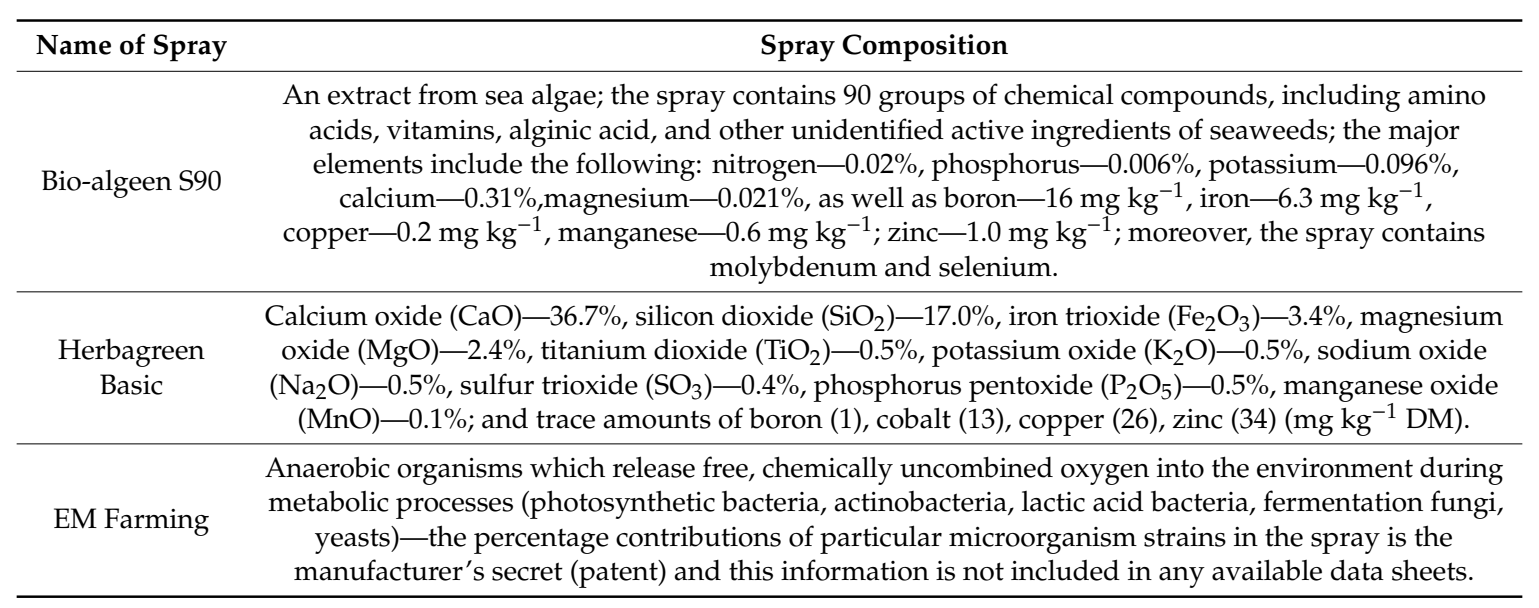

Before harvesting the chamomile crop, the following activities were performed:

- Evaluation of weed infestation of the crop using the agro-phytosociological method at the 2-3 leaf stage of chamomile (moving around the $6.25 \mathrm{~m}^{2}$ plots according to the scheme in Figure 2). Weed infestation intensity was determined using the Braun-Blanquet scale [15], where: - = no individuals; $r=1-3$ individuals; + means less than $1 \%$ of ground cover; $1=1-5 \%$ of ground cover; $2=5-25 \%$ of ground cover; $3=25-50 \%$ of ground cover $; 4=50-75 \%$ of ground cover; $5=75-100 \%$ of ground cover.

- Determination of health of chamomile plants according to a five-point scale carried out 15 days before harvest, based on 30 randomly selected plants per $6.25 \mathrm{~m}^{2}$ plot (Table 3).

- Over a period of 10 days before harvest of chamomile, evaluation of weed infestation of the plantation was performed by the dry-weight-rank method (number and air dry weight of weeds as well as their botanical composition) using a $0.25 \times 1.0 \mathrm{~m}$ quadrat frame (Figure 3) in 4 randomly selected places in each $6.25 \mathrm{~m}^{2}$ plot. The frame was placed in the randomly selected places in 
each plot (Figure 4), taking care not to damage chamomile plants. Within the frame, weeds were cut down just above ground and subsequently the species composition and number of weeds were determined. Next, weeds collected from 4 replicates in a given plot were combined into a composite sample and placed in paper bags with labels (plot number). The collected weed samples were dried in a plant house, bringing them slowly to air-dry weight.

Table 3. The scale used to determine health of chamomile plants.

\begin{tabular}{cc}
\hline Degree of Health & \% of Plants Infected \\
\hline I & $1-10$ \\
II & $11-25$ \\
III & $26-50$ \\
IV & $51-75$ \\
V & $76-100$ \\
\hline
\end{tabular}

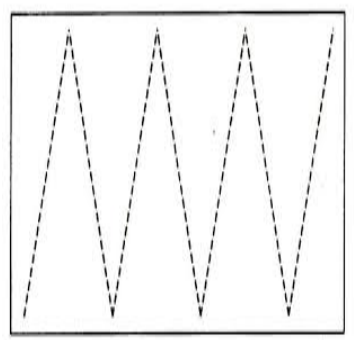

Figure 2. Agro-phytosociological method scheme-in each $6.25 \mathrm{~m}^{2}$ plot.

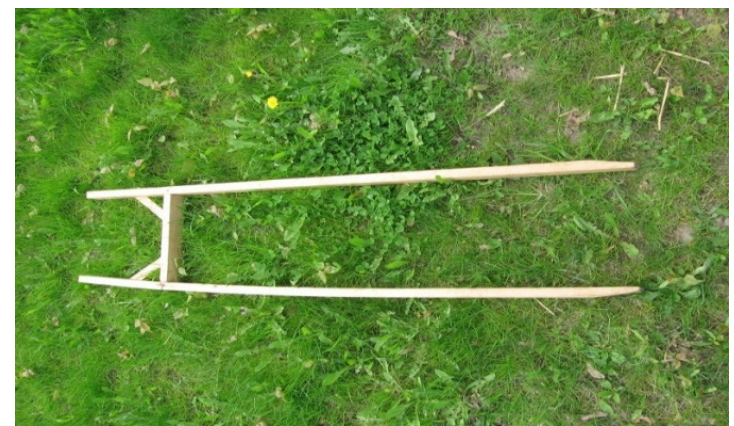

Figure 3. Frame $(0.25 \mathrm{~m} \times 1.0 \mathrm{~m})$ used in this research.

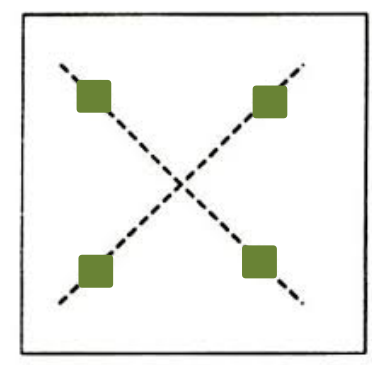

Figure 4. Weed infestation evaluation scheme-in each $6.25 \mathrm{~m}^{2}$ plot.

\section{Statistical Analysis}

Analysis of variance (ANOVA) was used to statistically analyze the results by employing Statistica PL 13.3, while Tukey's test was applied to determine HSD (Honest Significant Difference) values at $p<0.05$. The results tables show the mean for the study period because the year-to-year differences between the characteristics analyzed were statistically not significant. No significant interactions were 
found between the main experimental factors: cultivars, foliar sprays and row spacing. The statistical calculations also included the standard deviation (SD) and the coefficient of variation (CV). Correlation coefficients ( $r$ ) between the quantitative weed infestation indicators for the chamomile crop and the level of health of chamomile plants were also calculated.

\section{Results}

\subsection{Weed Infestation of the Chamomile Crop}

The first stage of evaluation of the chamomile plantation was to analyze in-crop weed infestation at the 2-3 leaf stage of this herbal plant. The evaluation performed using the agro-physiological method allowed the intensity of occurrence of dominant weed species to be determined. The data included in Tables 4 and 5 show that 7-11 annual weed species and 1-2 perennial species occurred in crops of the cultivars "Złoty Łan" and "Mastar", depending on the experimental plots included in the experimental design. Galeopsis tetrahit and Viola arvensis were predominant in the weed flora, Scleranthus annuus, Spergula arvensis, and Juncus bufonius were found at a medium level, while the other weed species occurred at the lowest level (r) or were found not to occur at all in some plots. It should be indicated that at the 2-3 leaf stage of chamomile the effect of different row spacings on weed infestation was not yet observed and that the foliar sprays had not been applied yet, either.

Number of weeds in the chamomile crop determined several days before its harvest was independent of the cultivar and almost identical values were found for the "Złoty Łan" and "Mastar" crops (Table 6). However, number of weeds as affected by row spacing exhibited significant relationships. Denser sowing of chamomile (at a row spacing of $30 \mathrm{~cm}$ ) promoted a reduction in the number of weeds by about $20 \%$ compared to a row spacing of $40 \mathrm{~cm}$. Some of the foliar sprays had a statistically proven effect on decreasing the number of weeds in chamomile crops-single spraying with the bioproducts Herbagreen Basic and Bio-algeen as well as double spraying with EM Farming promoted a reduction in the number of weeds by about $23 \%$ compared to the control treatment.

Table 4. Number and species composition of weeds found in the crop of the chamomile cultivar "Złoty Łan" at the 2-3 leaf stage of this herbal plant.

\begin{tabular}{|c|c|c|c|c|c|c|c|c|c|c|c|c|c|c|}
\hline \multirow{2}{*}{ Species } & \multicolumn{7}{|c|}{ Row Spacing-40 cm } & \multicolumn{7}{|c|}{ Row Spacing-30 cm } \\
\hline & $\mathbf{A}^{*}$ & B & $\mathrm{C}$ & $\mathrm{D}$ & $\mathrm{E}$ & $\mathbf{F}$ & G & A & B & $\mathrm{C}$ & D & $\mathbf{E}$ & $\mathbf{F}$ & G \\
\hline \multicolumn{15}{|l|}{ Annual } \\
\hline Galeopsis tetrahit L. & $1 * *$ & + & + & + & 1 & + & + & + & + & + & + & + & + & + \\
\hline Viola arvensis Murray & + & 1 & 1 & + & + & + & 1 & 1 & + & + & + & + & + & + \\
\hline Juncus bufonius L. & + & $\mathrm{r}$ & $\mathrm{r}$ & + & + & $\mathrm{r}$ & + & + & $\mathrm{r}$ & $\mathrm{r}$ & $\mathrm{r}$ & $\mathrm{r}$ & + & $\mathrm{r}$ \\
\hline Spergula arvensis L. & + & $\mathrm{r}$ & $\mathrm{r}$ & $\mathrm{r}$ & + & + & + & + & + & $\mathrm{r}$ & $\mathrm{r}$ & $\mathrm{r}$ & $\mathrm{r}$ & $\mathrm{r}$ \\
\hline Scleranthus annuus L. & + & + & + & + & + & + & + & + & + & + & + & + & + & + \\
\hline Geranium pusillum L. & + & + & $\mathrm{r}$ & $\mathrm{r}$ & + & - & $\mathrm{r}$ & $\mathrm{r}$ & - & $\mathrm{r}$ & - & + & + & + \\
\hline Erigeron canadensis (L.) Cronquist) & $\mathrm{r}$ & $\mathrm{r}$ & + & - & + & $\mathrm{r}$ & $\mathrm{r}$ & + & $\mathrm{r}$ & - & + & $\mathrm{r}$ & $\mathrm{r}$ & $\mathrm{r}$ \\
\hline Tripleurospermum maritimum (L.) W. D. J. Koch & $\mathrm{r}$ & $\mathrm{r}$ & $\mathrm{r}$ & $\mathrm{r}$ & - & - & - & $\mathrm{r}$ & $\mathrm{r}$ & $\mathrm{r}$ & - & - & $\mathrm{r}$ & $\mathrm{r}$ \\
\hline Polygonum convolvulus L. & $\mathrm{r}$ & - & - & - & - & - & $\mathrm{r}$ & $\mathrm{r}$ & $\mathrm{r}$ & $\mathrm{r}$ & - & - & - & - \\
\hline Chenopodium album L. & - & - & - & - & $\mathrm{r}$ & $\mathrm{r}$ & - & $\mathrm{r}$ & - & $\mathrm{r}$ & $\mathrm{r}$ & - & - & - \\
\hline Veronica arvensis L. & - & - & - & - & $\mathrm{r}$ & - & $\mathrm{r}$ & - & $\mathrm{r}$ & - & - & - & - & - \\
\hline Erodium cicutarium (L.) L'Her. & $\mathrm{r}$ & - & $\mathrm{r}$ & $\mathrm{r}$ & - & - & $\mathrm{r}$ & - & $\mathrm{r}$ & $\mathrm{r}$ & $\mathrm{r}$ & - & - & - \\
\hline Capsella bursa-pastoris (L.) Medik & - & - & - & $\mathrm{r}$ & $\mathrm{r}$ & $\mathrm{r}$ & - & - & $\mathrm{r}$ & - & - & - & - & - \\
\hline Number of annual species & 10 & 8 & 9 & 9 & 10 & 8 & 10 & 10 & 11 & 10 & 8 & 7 & 8 & 8 \\
\hline \multicolumn{15}{|l|}{ Perennial } \\
\hline Elymus repens (L.) Gould & $\mathrm{r}$ & $\mathrm{r}$ & $\mathrm{r}$ & - & $\mathrm{r}$ & $\mathrm{r}$ & $\mathrm{r}$ & $\mathrm{r}$ & $\mathrm{r}$ & - & $\mathrm{r}$ & $\mathrm{r}$ & $\mathrm{r}$ & $\mathrm{r}$ \\
\hline Convolvulus arvensis L. & - & $\mathrm{r}$ & - & - & - & - & - & - & - & - & - & $\mathrm{r}$ & - & - \\
\hline Number of perennial species & 1 & 2 & 1 & 0 & 1 & 1 & 1 & 1 & 1 & 0 & 1 & 2 & 1 & 1 \\
\hline
\end{tabular}


Table 5. Number and species composition of weeds found in the crop of the chamomile cultivar "Mastar" at the 2-3 leaf stage of this herbal plant.

\begin{tabular}{|c|c|c|c|c|c|c|c|c|c|c|c|c|c|c|}
\hline \multirow{2}{*}{ Species } & \multicolumn{7}{|c|}{ Row Spacing-40 cm } & \multicolumn{7}{|c|}{ Row Spacing-30 cm } \\
\hline & $\mathbf{A}^{*}$ & B & $\mathrm{C}$ & $\mathbf{D}$ & $E$ & F & G & $\mathbf{A}$ & B & $\mathrm{C}$ & D & $E$ & $F$ & G \\
\hline \multicolumn{15}{|l|}{ Annual } \\
\hline Galeopsis tetrahit L. & $1 * *$ & 1 & + & 1 & + & 1 & + & 1 & + & 1 & + & + & + & + \\
\hline Viola arvensis Murray & + & + & 1 & 1 & 1 & 1 & 1 & 1 & 1 & + & 1 & 1 & + & + \\
\hline Juncus bufonius L. & + & + & $\mathrm{r}$ & + & $\mathrm{r}$ & + & + & + & + & + & $\mathrm{r}$ & $\mathrm{r}$ & + & $\mathrm{r}$ \\
\hline Spergula arvensis L. & + & + & + & $\mathrm{r}$ & $\mathrm{r}$ & $\mathrm{r}$ & $\mathrm{r}$ & + & + & $\mathrm{r}$ & $\mathrm{r}$ & $\mathrm{r}$ & $\mathrm{r}$ & $\mathrm{r}$ \\
\hline Scleranthus annuus L. & + & $\mathrm{r}$ & $\mathrm{r}$ & + & $\mathrm{r}$ & + & + & + & $\mathrm{r}$ & $\mathrm{r}$ & + & $\mathrm{r}$ & + & + \\
\hline Geranium pusillum L. & + & + & - & $\mathrm{r}$ & + & - & - & $\mathrm{r}$ & - & $\mathrm{r}$ & - & + & + & + \\
\hline Erigeron canadensis (L.) Cronquist) & $\mathrm{r}$ & + & + & - & + & $\mathrm{r}$ & $\mathrm{r}$ & + & $\mathrm{r}$ & - & + & $\mathrm{r}$ & $\mathrm{r}$ & $\mathrm{r}$ \\
\hline Tripleurospermum maritimum (L.) W. D. J. Koch & $\mathrm{r}$ & $\mathrm{r}$ & - & $\mathrm{r}$ & - & $\mathrm{r}$ & - & $\mathrm{r}$ & - & $\mathrm{r}$ & - & - & $\mathrm{r}$ & $\mathrm{r}$ \\
\hline Polygonum convolvulus L. & $\mathrm{r}$ & $\mathrm{r}$ & - & - & $\mathrm{r}$ & - & - & $\mathrm{r}$ & - & $\mathrm{r}$ & - & $\mathrm{r}$ & - & - \\
\hline Chenopodium album $\mathrm{L}$. & $\mathrm{r}$ & $\mathrm{r}$ & - & - & $\mathrm{r}$ & - & - & $\mathrm{r}$ & $\mathrm{r}$ & - & $\mathrm{r}$ & - & - & - \\
\hline Veronica arvensis $\mathrm{L}$. & - & - & - & $\mathrm{r}$ & $\mathrm{r}$ & - & $\mathrm{r}$ & - & $\mathrm{r}$ & - & - & - & - & - \\
\hline Erodium cicutarium (L.) L'Her. & $\mathrm{r}$ & - & $\mathrm{r}$ & - & - & $\mathrm{r}$ & $\mathrm{r}$ & - & $\mathrm{r}$ & - & $\mathrm{r}$ & - & $\mathrm{r}$ & - \\
\hline Capsella bursa-pastoris (L.) Medik & - & $\mathrm{r}$ & $\mathrm{r}$ & - & - & - & - & - & - & - & - & - & - & - \\
\hline Number of annual species & 11 & 11 & 8 & 8 & 10 & 8 & 8 & 10 & 9 & 8 & 8 & 8 & 9 & 8 \\
\hline \multicolumn{15}{|l|}{ Perennial } \\
\hline Elymus repens (L.) Gould & $\mathrm{r}$ & $\mathrm{r}$ & $\mathrm{r}$ & $\mathrm{r}$ & $\mathrm{r}$ & $\mathrm{r}$ & $\mathrm{r}$ & $\mathrm{r}$ & $\mathrm{r}$ & - & $\mathrm{r}$ & $\mathrm{r}$ & - & $\mathrm{r}$ \\
\hline Convolvulus arvensis $\mathrm{L}$. & $\mathrm{r}$ & - & - & - & $\mathrm{r}$ & - & - & - & $\mathrm{r}$ & - & - & $\mathrm{r}$ & - & - \\
\hline Equisetum arvense $\mathrm{L}$. & - & - & - & $\mathrm{r}$ & - & $\mathrm{r}$ & - & - & - & $\mathrm{r}$ & - & - & - & - \\
\hline Number of perennial species & 2 & 1 & 1 & 2 & 2 & 2 & 1 & 1 & 2 & 1 & 1 & 2 & 0 & 1 \\
\hline
\end{tabular}

Table 6. Number of weeds in the chamomile crop (plants per $\mathrm{m}^{-2}$ )—evaluation before harvest of the herbal crop.

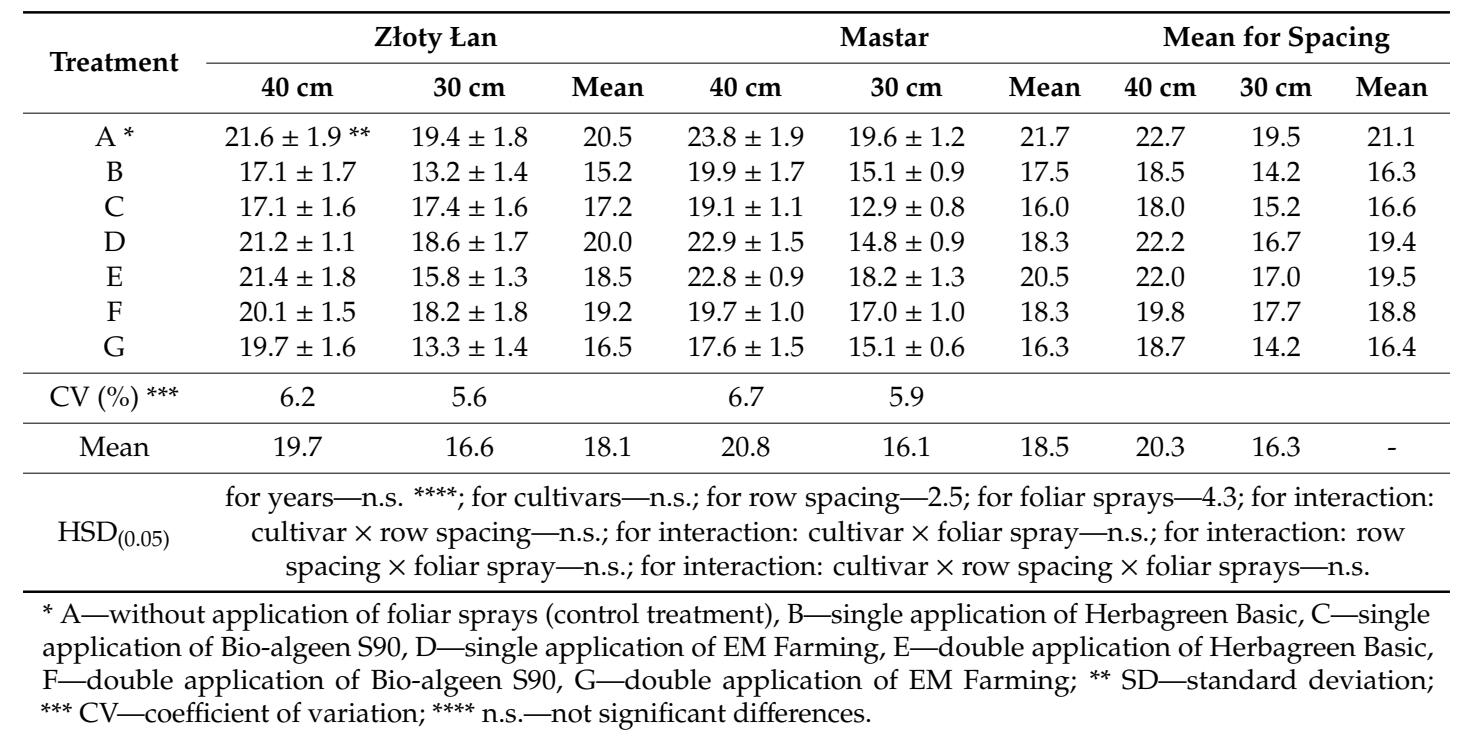

The cultivar factor did not also have a major influence on the dry weight of weeds in the chamomile crop (Table 7). The weed infestation indicator in question was however significantly dependent on row spacing - the wider row spacing $(40 \mathrm{~cm})$ contributed to a higher weight of weeds in the crop by about $35 \%$ relative to a spacing of $30 \mathrm{~cm}$. Among the foliar sprays used, Bio-algeen (applied once and twice) and EM Farming (applied twice) had a statistically significant effect on decreasing the dry weight of 
weeds in the chamomile crop. In the case of the other bioproduct application treatment combinations, the bioproducts were found to tend to decrease the weed weight.

Table 7. Dry weight of weeds in the chamomile crop $\left(\mathrm{g} \mathrm{m}^{-2}\right)$ - evaluation before harvest of the herbal crop.

\begin{tabular}{|c|c|c|c|c|c|c|c|c|c|}
\hline \multirow{2}{*}{ Treatment } & \multicolumn{3}{|c|}{ Złoty Lan } & \multicolumn{3}{|c|}{ Mastar } & \multicolumn{3}{|c|}{ Mean for Row Spacing } \\
\hline & $40 \mathrm{~cm}$ & $30 \mathrm{~cm}$ & Mean & $40 \mathrm{~cm}$ & $30 \mathrm{~cm}$ & Mean & $40 \mathrm{~cm}$ & $30 \mathrm{~cm}$ & Mean \\
\hline$A^{*}$ & $15.01 \pm 1.22 * *$ & $9.23 \pm 0.87$ & 12.12 & $15.41 \pm 1.90$ & $10.73 \pm 0.92$ & 13.07 & 15.21 & 9.98 & 12.59 \\
\hline B & $11.77 \pm 0.74$ & $6.15 \pm 0.93$ & 8.96 & $14.78 \pm 0.99$ & $7.43 \pm 0.58$ & 11.10 & 13.27 & 6.79 & 10.03 \\
\hline $\mathrm{C}$ & $7.28 \pm 0.71$ & $6.81 \pm 0.66$ & 7.04 & $15.95 \pm 1.33$ & $4.68 \pm 0.42$ & 10.31 & 11.61 & 5.74 & 8.67 \\
\hline $\mathrm{D}$ & $11.52 \pm 0.86$ & $7.45 \pm 0.91$ & 9.48 & $10.67 \pm 0.83$ & $7.74 \pm 0.61$ & 9.20 & 11.09 & 7.59 & 9.34 \\
\hline E & $12.43 \pm 1.04$ & $9.74 \pm 0.65$ & 11.08 & $11.31 \pm 0.92$ & $11.15 \pm 0.79$ & 11.23 & 11.87 & 10.52 & 11.19 \\
\hline $\mathrm{F}$ & $8.91 \pm 0.83$ & $8.80 \pm 0.52$ & 8.85 & $8.66 \pm 0.49$ & $6.23 \pm 0.47$ & 7.44 & 8.78 & 7.51 & 8.14 \\
\hline G & $11.33 \pm 0.92$ & $5.32 \pm 0.39$ & 8.32 & $9.15 \pm 0.59$ & $6.67 \pm 0.56$ & 7.91 & 10.24 & 5.99 & 8.11 \\
\hline $\mathrm{CV}(\%)^{* * *}$ & 4.8 & 5.2 & & 5.1 & 6.1 & & & & \\
\hline Mean & 11.17 & 7.64 & 9.41 & 12.27 & 7.80 & 10.03 & 11.72 & 7.72 & - \\
\hline $\operatorname{HSD}_{(0.05)}$ & $\begin{array}{c}\text { for years- } \\
\text { cultivar } \times \text { rov }\end{array}$ & $\begin{array}{l}\text { **; for cu } \\
\text { acing-n. } \\
\text { ar spray }\end{array}$ & rinte & $\begin{array}{l}\text { for row } \mathrm{sp} \\
\text { tion: cultiv }\end{array}$ & $\begin{array}{l}-2.79 ; \text { fo } \\
\text { foliar spra }\end{array}$ & $\begin{array}{l}\mathrm{arsp} \\
. \mathrm{s.} ; \mathrm{f}\end{array}$ & $\begin{array}{l}-3.5 \\
\text { terac }\end{array}$ & $\begin{array}{l}\text { or int } \\
\text { : row }\end{array}$ & $\begin{array}{l}\text { tion: } \\
\text { cing } \times\end{array}$ \\
\hline
\end{tabular}

* A-without application of foliar sprays (control treatment), B-single application of Herbagreen Basic, C-single application of Bio-algeen S90, D—single application of EM Farming, E-double application of Herbagreen Basic, F-double application of Bio-algeen S90, G-double application of EM Farming; ** SD—standard deviation; *** CV—coefficient of variation; n.s. - not significant differences.

Table 8 presents the number of dominant weed species in crops of the chamomile cultivars "Złoty Łan" and "Mastar" relative to the other experimental factors (foliar sprays, row spacing). The data contained in this table show that 10-16 annual weed species and 1-3 perennial species occurred in crops of both chamomile cultivars, and hence 5-6 species more than the numbers found during the initial plantation development period (2-3 leaf stage of chamomile). The following species were dominant in terms of numbers: Viola arvensis, Galeopsis tetrahit, Spergula arvensis, Juncus bufonius, and Scleranthus annuus, and thus the species that had been observed to occur with greater intensity already during the first (agro-phytosociological) evaluation of weed infestation. When analyzing the effect of row spacing in chamomile crops on weed infestation, we note that it had no impact on the number of annual or perennial weed species, regardless of the foliar sprays, but the total number of annual weeds was found to be lower (by $21 \%$ ) under narrow row spacing conditions (a spacing of $30 \mathrm{~cm}$ ) compared to a spacing of $40 \mathrm{~cm}$. The foliar sprays used in the experiment had a different impact on the number of annual weeds and the number of annual weed species, but did not modify the perennial flora almost at all. Overall, it can be stated that the foliar sprays had an indirect effect on decreasing the number of annual weeds in comparison with the control plots. The largest reduction (by about 19-20\%) in the number of annual weeds was recorded under the influence of the bioproducts Herbagreen Basic and Bio-algeen applied once (treatments B and C) and under the influence of Effective Microorganisms (treatment G). The cultivar factor had no impact on the number of weeds and their species composition (Table 8). 
Table 8. Number and species composition of weeds in the chamomile crop depending on the experimental factors-evaluation before harvest of the herbal crop.

\begin{tabular}{|c|c|c|c|c|c|c|c|c|c|c|c|}
\hline \multirow{2}{*}{ Species } & \multicolumn{7}{|c|}{ Foliar Spray Application Treatments } & \multicolumn{2}{|c|}{ Row Spacing } & \multicolumn{2}{|c|}{ Cultivar } \\
\hline & $\mathbf{A}^{*}$ & B & $\mathrm{C}$ & $\mathbf{D}$ & E & F & G & $40 \mathrm{~cm}$ & $30 \mathrm{~cm}$ & Złoty Łan & Mastar \\
\hline \multicolumn{12}{|l|}{ Annual } \\
\hline Viola arvensis Murray & 4.3 & 3.0 & 3.3 & 3.5 & 2.7 & 2.9 & 2.8 & 3.9 & 2.7 & 3.5 & 3.1 \\
\hline Spergula arvensis L. & 3.9 & 2.4 & 3.1 & 2.4 & 2.2 & 2.1 & 2.4 & 3.1 & 2.1 & 2.5 & 2.7 \\
\hline Galeopsis tetrahit $\mathrm{L}$. & 3.7 & 3.1 & 2.9 & 2.5 & 3.4 & 2.8 & 2.9 & 3.4 & 2.4 & 2.7 & 3.1 \\
\hline Juncus bufonius L. & 1.9 & 1.4 & 1.5 & 1.5 & 1.2 & 2.6 & 2.1 & 2.2 & 1.5 & 1.5 & 2.1 \\
\hline Scleranthus annuus L. & 1.1 & 1.9 & 1.4 & 1.2 & 2.0 & 1.5 & 1.2 & 1.5 & 1.6 & 1.5 & 1.2 \\
\hline Erigeron canadensis (L.) Cronquist) & 0.8 & 0.7 & 0.3 & 1.1 & 0.7 & 0.9 & 0.5 & 0.7 & 0.6 & 0.8 & 0.9 \\
\hline $\begin{array}{l}\text { Tripleurospermum maritimum (L.) } \\
\text { W. D. J. Koch }\end{array}$ & 0.7 & 0.4 & 0.1 & 0.4 & 0.3 & 0.7 & 0.9 & 0.7 & 0.4 & 0.5 & 0.6 \\
\hline Echinochloa crus-galli (L.) P. Beauv. & 0.7 & 0.2 & 0.4 & 0.7 & 1.2 & 1.1 & 0.7 & 0.6 & 0.7 & 0.9 & 0.4 \\
\hline Geranium pusillum L. & 0.6 & 0.5 & 0.2 & 1.5 & 1.0 & 0.5 & 0.3 & 0.6 & 0.8 & 0.7 & 0.8 \\
\hline Setaria pumila (Poir.) Roem. & 0.5 & 0.4 & - & 0.4 & 0.2 & 0.4 & 0.2 & 0.3 & 0.1 & 0.3 & 0.2 \\
\hline Polygonum convolvulus $\mathrm{L}$. & 0.5 & 0.3 & 0.6 & 0.3 & 0.5 & 0.8 & 0.4 & 0.4 & 0.5 & 0.6 & 0.5 \\
\hline Hypericum humifusum L. & 0.5 & 0.5 & 0.8 & 0.6 & 0.7 & 0.4 & 0.3 & 0,5 & 0.7 & 0.7 & 0.3 \\
\hline Chenopodium album $\mathrm{L}$. & 0.3 & 0.2 & - & 0.4 & 0.4 & - & 0.6 & 0.4 & 0.2 & 0.1 & 0.5 \\
\hline Capsella bursa-pastoris (L.) Medik & 0.3 & 0.1 & 0.1 & 0.5 & 0.5 & 0.6 & 0.3 & 0.2 & 0.4 & 0.2 & 0.3 \\
\hline Veronica arvensis L. & 0.1 & - & 0.2 & 0.3 & 0.3 & 0.4 & 0.2 & 0.3 & 0.1 & 0.2 & 0.2 \\
\hline Erodium cicutarium (L.) L'Her. & - & 0.1 & 0.2 & 0.2 & 0.5 & - & 0.2 & 0.1 & 0.2 & 0.2 & 0.1 \\
\hline Galinsoga parviflora Cav. & - & - & 0.1 & 0.5 & 0.2 & 0.3 & - & 0.1 & 0.2 & 0.1 & 0.2 \\
\hline Number of annual weeds & 19.6 & 15.1 & 15.2 & 18.1 & 17.8 & 17.7 & 15.8 & 19.1 & 15.1 & 17.0 & 17.1 \\
\hline Number of annual species & 15 & 15 & 15 & 17 & 17 & 15 & 16 & 17 & 17 & 17 & 17 \\
\hline \multicolumn{12}{|l|}{ Perennial } \\
\hline Elymus repens (L.) Gould & 1.1 & 0.7 & 1.1 & 0.9 & 1.3 & 0.9 & 0.6 & 1.0 & 0.9 & 0.7 & 1.0 \\
\hline Equisetum arvense $\mathrm{L}$. & 0.3 & 0.3 & 0.2 & 0.1 & - & 0.2 & - & 0.1 & 0.2 & 0.1 & 0.1 \\
\hline Convolvulus arvensis $\mathrm{L}$. & 0.1 & 0.3 & 0.1 & 0.4 & 0.4 & - & - & 0.1 & 0.1 & 0.2 & 0.3 \\
\hline Number of perennial weeds & 1.5 & 1.2 & 1.4 & 1.3 & 1.7 & 1.1 & 0.6 & 1.2 & 1.2 & 1.1 & 1.4 \\
\hline Number of perennial species & 3 & 3 & 3 & 3 & 2 & 2 & 1 & 3 & 3 & 3 & 3 \\
\hline
\end{tabular}

\subsection{Health of Chamomile Plants}

Infection of chamomile plants with fungal pathogens was at a low level (ranging on average 2.7-10.1\%). Nonetheless, the experimental factors were found to significantly affect the analyzed trait (Table 9). The chamomile cultivar "Mastar" was characterized by almost twice higher susceptibility to infection with fungal diseases than cv. "Złoty Łan", which is probably attributable to its poor adaptation to local habitat conditions. The foliar sprays contributed to a significant reduction in the occurrence of fungal diseases in relation to the level of occurrence of fungal pathogens in the control plots (without application of the bioproducts). Herbagreen Basic and Bio-algeen applied twice during the growing season of this herbal plant had a particularly beneficial effect on the health of chamomile plants. Regardless of the foliar sprays, chamomile plants sown at a row spacing of $40 \mathrm{~cm}$ were found to be significantly healthier in comparison with the narrower spacing $(30 \mathrm{~cm})$. The greater infection of chamomile plants with fungal diseases in the control treatments (without application of the bioproducts) and in the case of the narrower row spacing was positively correlated with the higher number of weeds in these treatments, as evidenced by the calculated correlation coefficients Table 10. 
Table 9. Health of chamomile plants (\%)—evaluation before harvest of the herbal crop.

\begin{tabular}{cccccccccc}
\hline \multirow{2}{*}{ Treatment } & \multicolumn{3}{c}{ Złoty Lan } & \multicolumn{3}{c}{ Mastar } & \multicolumn{3}{c}{ Mean for Row Spacing } \\
\cline { 2 - 10 } & $\mathbf{4 0} \mathbf{~ c m}$ & $\mathbf{3 0} \mathbf{~ c m}$ & Mean & $\mathbf{4 0} \mathbf{~ c m}$ & $\mathbf{3 0} \mathbf{~ c m}$ & Mean & $\mathbf{4 0} \mathbf{~ c m}$ & $\mathbf{3 0} \mathbf{~ c m}$ & Mean \\
\hline A $^{*}$ & $6.2 \pm 0.9 * *$ & $7.9 \pm 1.1$ & 7.0 & $11.5 \pm 1.3$ & $15.4 \pm 1.7$ & 13.4 & 8.8 & 11.6 & 10.2 \\
B & $3.4 \pm 0.6$ & $4.5 \pm 0.6$ & 3.9 & $7.5 \pm 1.0$ & $8.0 \pm 0.9$ & 7.7 & 5.4 & 6.2 & 5.8 \\
C & $3.2 \pm 0.6$ & $3.8 \pm 0.7$ & 3.5 & $6.1 \pm 0.7$ & $6.5 \pm 0.8$ & 6.3 & 4.6 & 5.1 & 4.8 \\
D & $4.0 \pm 0.7$ & $5.1 \pm 0.8$ & 4.5 & $8.4 \pm 0.5$ & $9.7 \pm 0.9$ & 9.0 & 6.2 & 7.4 & 6.8 \\
E & $2.0 \pm 0.3$ & $2.4 \pm 0.5$ & 2.2 & $3.1 \pm 0.3$ & $3.4 \pm 0.4$ & 3.2 & 2.5 & 2.9 & 2.7 \\
F & $2.2 \pm 0.5$ & $2.8 \pm 0.6$ & 2.5 & $3.7 \pm 0.4$ & $4.0 \pm 0.5$ & 3.8 & 2.9 & 3.4 & 3.1 \\
G & $3.4 \pm 0.8$ & $4.1 \pm 0.9$ & 3.7 & $5.5 \pm 0.6$ & $6.2 \pm 0.7$ & 5.8 & 4.4 & 5.1 & 4.7 \\
\hline CV (\%) ${ }^{* * *}$ & 8.4 & 7.3 & & 12.5 & 13.2 & & & & \\
\hline Mean & 3.4 & 4.4 & 3.9 & 6.5 & 7.6 & 7.0 & 5.0 & 6.0 & - \\
\hline
\end{tabular}

for years-n.s. ${ }^{* * * *}$; for cultivars- 0.97 ; for row spacing -0.94 ; for foliar sprays -1.11 ; for interaction: $\mathrm{HSD}_{(0.05)} \quad$ cultivar $\times$ row spacing -n.s.; for interaction: cultivar $\times$ foliar spray - n.s.; for interaction: row spacing $\times$ foliar spray - n.s.; for interaction: cultivar $\times$ row spacing $\times$ foliar spray - n.s.

* A-without application of foliar sprays (control treatment), B-single application of Herbagreen Basic, C—single application of Bio-algeen S90, D-single application of EM Farming, E-double application of Herbagreen Basic, F-double application of Bio-algeen S90, G-double application of EM Farming; ** SD—standard deviation; *** $\mathrm{CV}$-coefficient of variation; ${ }^{* * * *}$ n.s. - not significant differences.

Table 10. Correlation coefficients ( $r$ ) between the number and weight of weeds in the crop and infection of chamomile plants with fungal diseases.

\begin{tabular}{|c|c|c|c|c|c|}
\hline \multirow{2}{*}{ Treatment } & \multirow{2}{*}{ Row Spacing $(\mathrm{cm})$} & \multicolumn{2}{|c|}{ Number of Weeds } & \multicolumn{2}{|c|}{ Weight of Weeds } \\
\hline & & Złoty Łan & Mastar & Złoty Łan & Mastar \\
\hline \multirow{2}{*}{$A *$} & 30 & $0.71 * *$ & $0.89 * *$ & 0.36 & $0.55^{* *}$ \\
\hline & 40 & $0.58^{* *}$ & $0.62^{* *}$ & 0.28 & 0.33 \\
\hline \multirow{2}{*}{ B } & 30 & 0.18 & 0.23 & 0.11 & 0.15 \\
\hline & 40 & 0.09 & 0.16 & 0.07 & 0.06 \\
\hline \multirow{2}{*}{$\mathrm{C}$} & 30 & 0.20 & 0.22 & 0.09 & 0.13 \\
\hline & 40 & 0.08 & 0.10 & 0.06 & 0.09 \\
\hline \multirow{2}{*}{$\mathrm{D}$} & 30 & 0.27 & 0.33 & 0.21 & 0.26 \\
\hline & 40 & 0.22 & 0.28 & 0.14 & 0.18 \\
\hline \multirow{2}{*}{$\mathrm{E}$} & 30 & 0.22 & 0.21 & 0.20 & 0.17 \\
\hline & 40 & 0.28 & 0.32 & 0.31 & 0.26 \\
\hline \multirow{2}{*}{$\mathrm{F}$} & 30 & 0.18 & 0.19 & 0.22 & 0.28 \\
\hline & 40 & 0.13 & 0.11 & 0.12 & 0.15 \\
\hline \multirow{2}{*}{ G } & 30 & 0.13 & 0.15 & 0.11 & 0.23 \\
\hline & 40 & 0.09 & 0.12 & 0.09 & 0.17 \\
\hline
\end{tabular}

* A-without application of foliar sprays (control treatment), B-single application of Herbagreen Basic, C—single application of Bio-algeen S90, D-single application of EM Farming, E-double application of Herbagreen Basic, F-double application of Bio-algeen S90, G-double application of EM Farming; ${ }^{* *}$ significant correlation coefficient $(0.05)$.

\section{Discussion}

There are few scientific studies regarding direct and indirect effects of foliar applied bioproducts on weed infestation and health of organically grown chamomile. Therefore, the discussion of these study results is based primarily on other researchers' reports dealing generally with the problem of weeds and fungal diseases in crop plantations grown in the organic system.

Segetal flora occurring in crop fields is one of the more important elements influencing the functioning of the entire agroecosystem. Its competitiveness against a crop and also its reproductive 
potential significantly impact agricultural production [16-18]. The farming system, which includes crop rotation, selection of varieties, fertilization method and level, and weed control methods, is of key significance for the preservation of the biodiversity of segetal flora in an agroecosystem [19-22].

The present study confirmed the research hypothesis and demonstrated lower weed infestation of chamomile crops fertilized with the foliar sprays. At the same time, greater richness of the segetal flora was observed in the plots where the foliar sprays were used. Foliar biological products (biostimulators, micronutrient fertilizers, Effective Microorganisms) contribute to greater resistance of a crop to unfavorable habitat conditions (including pressure from agricultural pests) through, among others, a faster generative growth rate. Due to this, the crop competes more effectively for light and nutrients with weeds $[3,13]$. In conventional agriculture, when crops are fertilized, for example, with soil applied mineral nitrogen, the result is that weeds, taking up $\mathrm{N}$ from the soil substrate, show an even greater growth rate than the crop [23]. In organic farming, weeds are perceived as an integral part of an agroecosystem [24]. If weeds occur in low numbers, but exhibit high species variation (greater biodiversity), they are even perceived as a positive aspect of an ecosystem $[25,26]$. The present study confirms this thesis because in the treatments with application of the foliar sprays the number and weight of weeds were observed to be lower, but at the same time exhibiting greater biodiversity in chamomile crops. Furthermore, this research reveals that the weed species composition determined before harvest of chamomile was slightly greater (by only 5-6 species) than that found at the 2-3 leaf stage of chamomile. This situation is explained by other authors' studies which reveal that in organic crops changes in weed species composition occur more slowly than changes in weed numbers [27]. This evidences relatively high stability of weed flora in such crops [28].

Another method to reduce weed infestation in organic plantations is to select an appropriate spacing of crop rows. If a narrower row spacing is used, weeds occurring in interrows of a crop have limited light access and competition with the crop is more difficult [29]. The results of the present study confirm this view because chamomile sown at the narrower row spacing $(30 \mathrm{~cm})$ exhibited a lower degree of weed infestation than at the wider spacing $(40 \mathrm{~cm})$. Kraska et al. [30] also recorded a lower number and weight of weeds in organically grown lentil crops in the case of the narrowest row spacing, which was $20 \mathrm{~cm}$. Kwiatkowski et al. [31], in turn, observed significantly lower weed infestation of a winter oilseed rape crop using a row spacing of $18 \mathrm{~cm}$ in comparison with a spacing of $30 \mathrm{~cm}$. Similar relationships (a lower degree of weed infestation of crops with narrowing row spacing) were also found by Lins and Boerboom [32] on the example of soybean as well as by Primot and Valantin-Morison [33] on the example of winter oilseed rape. Lutman et al. [34] also report on the importance of a higher crop density as regards competition with weeds in a study investigating the competitiveness of oilseed rape against the dominant species Stellaria media in oilseed rape crops.

The cultivar factor can also be of significance in controlling weed infestation of crops. This research did not find significant differences in the quantitative weed infestation indicators between the chamomile cultivars "Złoty Łan" and "Mastar". Feledyn-Szewczyk [35] also found a lower effect of the crop variety on the level and state of weed infestation on the example of winter wheat.

The results of this study show infection of chamomile with fungal diseases to be significantly lower compared to the control plots (without application of the bioproducts), regardless of the bioproduct used (foliar fertilizer, biostimulator, Effective Microorganisms) and the number of its applications (single or double). Bioproducts are not directly fungicides [36]. Their indirect role in controlling plant infection with fungal diseases consists in "feeding plants" and enhancing their resistance to environmental stresses as well as to fungal and bacterial pathogen activity $[37,38]$. Numerous scientific studies confirm the positive effects of various biological products on the biometric characteristics, nutritional composition, and health of herbal, horticultural, cereal, and root plants [39-44].

While being effective in reducing weed infestation in a field (as evidenced by this research), a dense crop (a smaller interrow width) poses at the same time a greater risk of development of fungal diseases, which is promoted by, among others, higher humidity and temperature in a dense crop [45,46]. As shown by the present study, infection of a crop with fungal diseases is due not only to the crop 
density, but also results from a higher number and weight of weeds in the crop, which are hosts for many disease-causing fungi $[47,48]$. Resistance to fungal diseases can also be driven by the cultivar factor $[45,49]$. This is confirmed by the results of this study because infection of the chamomile cultivar "Złoty Łan" (better adapted to habitat conditions of the central Lublin region, Poland) was found to be significantly lower than in the case of cv. "Mastar".

This research demonstrates that in the case of the bioproducts Herbagreen Basic and Bio-algeen single application of these sprays proved to be sufficient in controlling agricultural pests, with its effect being similar to that of double application. The studies by Kwiatkowski [3] on chamomile and Kwiatkowski et al. [4] on common thyme also confirm the high efficacy of single application of bioproducts.

\section{Conclusions}

Weed species composition was quite a stable characteristic (the number of weed species in the chamomile crop during the period from the 2-3 leaf stage until its harvest increased only slightly). The experimental factors modified the number and species composition of the weed flora to a small degree. Sixteen annual weed species and 3 perennial species were found in chamomile crops. Viola arvensis, Galeopsis tetrahit, Spergula arvensis, Juncus bufonius, and Scleranthus annus dominated in terms of numbers.

Among the foliar sprays tested in this experiment, the bioproducts Bio-algeen and Effective Microorganisms (number and weight of weeds) as well as Herbagreen Basic (number of weeds) showed the most beneficial effect on reducing the quantitative weed infestation indicators. All the foliar sprays used in this experiment significantly improved the health of chamomile plants.

From the point of view of plant health, the wider spacing $(40 \mathrm{~cm})$ undoubtedly proved to be more beneficial for the cultivation of chamomile. The narrower row spacing $(30 \mathrm{~cm})$, on the other hand, reduced weed infestation of the chamomile crop more effectively.

The chamomile cultivar "Złoty Łan" exhibited better plant health when grown organically than the cultivar "Mastar". Nevertheless, both chamomile cultivars were characterized by a similar degree of weed infestation of the plantation, regardless of the other experimental factors.

Author Contributions: C.A.K., M.H. conceptualization; C.A.K., M.H., E.H. formal analysis; C.A.K., M.H. investigation and methodology; C.A.K., E.H., M.H. resources, C.A.K., E.H. writing-original draft. All authors have read and agreed to the published version of the manuscript.

Acknowledgments: This research was supported by the Ministry of Agriculture and Rural Development in Poland.

Conflicts of Interest: The authors declare no conflict of interest.

\section{References}

1. Srivastava, J.K.; Shankar, E.; Gupta, S. Chamomile. A herbal medicine of the past with bright future. Mol. Med. Rep. 2010, 3, 895-901. [CrossRef]

2. Cavalieri, E.; Rigo, A.; Bonifacio, M.; Carcereri de Prati, A.; Guardalben, E.; Bergamini, C.; Fato, R.; Pizzolo, G.; Suzuki, H.; Vinante, F. Pro-apoptotic activity of $\alpha$-bisabolol in preclinical models of primary human acute leukemia cells. J. Transl. Med. 2011, 9, 45. [CrossRef]

3. Kwiatkowski, C.A. Yield and quality of chamomile (Chamomila recutita (L.) Rausch.) raw material depending on selected foliar sprays and plant spacing. Acta Sci. Pol. Hortorum Cultus 2015, 14, 143-156.

4. Kwiatkowski, C.A.; Haliniarz, M.; Harasim, E.; Kołodziej, B.; Yakimovich, A. Foliar applied biopreparations as a natural method to increase the productivity of garden thyme (Thymus vulgaris L.) and to improve the quality of herbal raw material. Acta Sci. Pol. Hortorum Cultus 2020, 19, 107-118. [CrossRef]

5. Radosevich, S.; Holt, J.; Ghersa, C. Ecology of Weeds and Invasive Plants: Relationship to Agriculture and Natural Resources Management, 3rd ed.; John Wiley\&Sons, Inc.: Hoboken, NJ, USA, 2007.

6. Rao, V.S. Principles of Weed Science. In Weed Biology and Ecology, 2nd ed.; Science Publishers, Inc.: Enfield, NH, USA, 2000. [CrossRef] 
7. Milberg, P.; Hallgren, E. Yield loess due to weeds in cereals and its large-scale variability in Sweden. Field Crops Res. 2004, 86, 199-209. [CrossRef]

8. Demjanová, E.; Macák, M.; Ćaloviü, I.; Majernik, F.; Týr, S.; Smatana, J. Effects of tillage systems and crop rotation on weed density, weed species composition and weed biomass in maize. Agron. Res. 2009, 7, 785-792.

9. Santin-Montanyáa, M.I.; Martin-Lammerding, D.; Walter, I.; Zembrana, E.; Tenorio, J.L. Effects of tillage, crop systems and fertilization of weed abundance and diversity in 4-year dry land winter wheat. Eur. J. Agron. 2013, 48, 43-49. [CrossRef]

10. Dolijanovic, Z.; Kovacevic, D.; Momirovic, Ä.; Oljaca, S.; Jovovic, Z. Effect of crop rotations on weed infestation in winter wheat. Bulg. J. Agric. Sci. 2014, 20, 416-420.

11. Datnoff, L.E.; Elmer, W.H.; Huber, D.M. (Eds.) . Mineral Nutrition and Plant Disease; APS Press: St. Paul, MN, USA, 2007.

12. Kwiatkowski, C.A.; Harasim, E.; Yakimovich, A.; Kołodziej, B.; Tomczyńska-Mleko, M. Evaluation of spent mushroom substrate, mineral NPK fertilization and manure fertilization on chamomile (Chamomilla recutita L. Rausch) yield and raw material quality. Acta Sci. Pol. Hortorum Cultus 2018, 17, 3-16. [CrossRef]

13. Javaid, A. Foliar application of effective microorganisms on pea an alternative fertilizer. Agron. Sustain. Dev. 2006, 26, 257-262. [CrossRef]

14. Dobromilska, R.; Mikiciuk, M.; Gubarewicz, K. Evaluation of cherry tomato yielding and fruit mineral composition after using of Bio-algeen S-90 preparation. J. Elem. 2008, 13, 491-499.

15. Braun-Blanquet, J. Pflanzensoziologie; Springer-Verlag: Wien, Austria, 1951.

16. Menalled, F. Weed Seedbank Dynamics \& Integrated Management of Agricultural Weeds. Bozeman: Extension Publication, Montana State University. Available online: https:/www.mssoy.org/uploads/files/ weed-seed-bank-mont (accessed on 12 May 2020).

17. Swanton, C.; Nkoa, R.; Blackshaw, R.E. Experimental methods for crop-weed competition studies. Weed Sci. 2015, 63, 2-11. [CrossRef]

18. Keller, M.; Böhringer, Ä.; Möhring, J.; Rueda-Ayala, V.; Gutjar, C.; Gerhards, R. Changes in weed communities, herbicides, yield levels and effect of weeds on yield in winter cereals based on three decades of field experiments in south-western Germany. Gesunde Pflanzen 2015, 67, 11-20. [CrossRef]

19. Lunkvist, A.; Salomonsson, L.; Karlsson, L.; Gustavsson, A.D. Effects of organic farming on weed flora composition in a long term perspective. Eur. J Agron. 2008, 28, 570-578. [CrossRef]

20. Edesi, L.; Järvan, M.; Adamson, A.; Lauringson, E.; Kuht, J. Weed species diversity and community composition in conventional and organic farming: A five-year experiment. Zemdirb. Agric. 2012, 99, 339-346.

21. Kolářová, M.; Tyšer, L.; Soukup, J. Weed species diversity in the Czech Republic under different farming and site conditions. Acta Univ. Agric. Silvic. Mendel. Brun. 2015, 63, 741-749. [CrossRef]

22. Petit, S.; Munier-Jolain, Ä.; Bretagnolle, V.; Bockstaller, C.; Gaba, S.; Cordeau, S.; Lechenet, M.; Mézière, D.; Colbach, N. Ecological intensification through pesticide reduction: Weed Control, Weed Biodiversity and Sustainability in Arable Farming. Environ. Manag. 2015, 56, 1078-1090. [CrossRef]

23. Blackshaw, R.E.; Brandt, R.N.; Janzen, H.H.; Entz, T.; Grant, C.A.; Derksen, D.A. Differential response of weed species to added nitrogen. Weed Biol. Ecol. 2003, 51, 532-539. [CrossRef]

24. Marshall, E.J.P.; Brown, V.K.; Boatman, N.D.; Lutman, P.J.W.; Squire, G.R.; Ward, L.K. The role of weeds in supporting biological diversity within crop fields. Weed Res. 2003, 43, 77-89. [CrossRef]

25. Baessler, C.; Klotz, S. Effects of changes in agricultural land-use on landscape structure and arable weed vegetation over the last 50 years. Agric. Ecosyst. Environ. 2006, 115, 3-50. [CrossRef]

26. Fried, G.; Petit, S.; Dessaint, F.; Reboud, X. Arable weed decline in Northern France: Crop edges as refugia for weed conservation? Biol. Conserv. 2009, 142, 238-243. [CrossRef]

27. Odum, E.P.; Park, T.Y.; Hutcheson, K. Comparison on the weedy vegetation in old-fields and crop fields on the same site reveals the fallowing crop fields does not result in seedbank buildup of agricultural weeds. Agric. Ecosyst. Environ. 1994, 49, 247-252. [CrossRef]

28. Zanin, G.; Otto, S.; Riello, L.; Borin, M. Ecological interpretation of weed flora dynamics under different tillage systems. Agric. Ecosyst. Environ. 1997, 66, 177-188. [CrossRef]

29. Alnenhofen, L.M.; Dekker, J. Complex regulation of Chenopodium album seed germination. Appl. Ecol. Environ. Sci. 2013, 1, 133-142. [CrossRef] 
30. Kraska, P.; Andruszczak, S.; Kwiecińska-Poppe, E.; Staniak, M.; Róźyło, K.; Rusecki, H. Supporting crop and different row spacing as factors influencing weed infestation in lentil crop and seed yield under organic farming conditions. Agronomy 2020, 10, 9. [CrossRef]

31. Kwiatkowski, C.A.; Gawęda, D.; Drabowicz, M.; Haliniarz, M. Effect of diverse fertilization, row spacing and sowing rate on weed infestation and yield of winter oilseed rape. Acta Sci. Pol. Agric. 2012, 11, 53-63.

32. Lins, R.D.; Boerboom, C.M. Effect of Soybean Row Spacing on Weed Competition. In Proceedings of the 2002 Wisconsin Fertilizer Aglime, and Pest Management Conference, Madison, WI, USA, 15-17 January 2002.

33. Primot, S.; Valantin-Morison, M.; Makowski, D. Predicting the risk of weed infestation in winter oilseed rape crops. Weed Res. 2006, 46, 22-33. [CrossRef]

34. Lutman, P.J.W.; Bowerman, P.; Palmer, G.M.; Whytock, G.P. Prediction of competition between oilseed rape and Stellaria media. Weed Res. 2000, 40, 255-269. [CrossRef]

35. Feledyn-Szewczyk, B. Comparison of the competitiveness of modern and old winter wheat cultivars in relation to weeds. J. Res. Appl. Agric. Eng. 2009, 54, 60-67.

36. Trewavas, A. Urban myths of organic farming. Nature 2001, 410, 409-410. [CrossRef]

37. De Ponti, T.; Rijk, B.; Van Ittersum, M.K. The crop yield gap between organic and conventional agriculture. Agric Syst. 2012, 108, 1-9. [CrossRef]

38. Du Jardin, P. Plant biostimulants: Definition, concept, main categories and regulation. Sci. Hortic. 2015, 196, 3-14. [CrossRef]

39. Elad, Y. Biological control of foliar pathogens by means of Trichoderma harzianum and potential modes of action. Crop Prot. 2000, 19, 709-714. [CrossRef]

40. Prokkola, S.; Kivijärvi, P. Effect of biological sprays on the incidence of grey mould, fruit yield and fruit quality in organic strawberry production. Agric. Food Sci. 2007, 16, 25-33. [CrossRef]

41. Jamiołkowska, A. The influence of bio-preparation Biosept 33 SL on fungi colonizing of sweet pepper plants (Capsicum annum L.) cultivated in the field. Electron. J. Polish Agric. Univ. Ser. Hortic. 2009, 12, 117.

42. Das, K.; Tiwari, R.K.S.; Shrivastava, D.K. Techniques for evaluation of medicinal plant products as antimicrobial agent: Current methods and future trends. J. Med. Plants Res. 2010, 4, 104-111. [CrossRef]

43. Escobar, Ä.; Solarte, V. Microbial diversity associated with organic fertilizer obtained by composting of agricultural waste. Int. J. Biosci. Biochem. Bioinform. 2015, 5, 70-79. [CrossRef]

44. De Pascale, S.; Rouphael, Y.; Colla, G. Plant biostimulants: Innovative tool for enhancing plant nutrition in organic farming. Eur. J. Hortic. Sci. 2017, 82, 277-285. [CrossRef]

45. Ballaré, C.L.; Mazza, C.A.; Austin, A.T.; Pierik, R. Canopy light and plant health. Plant Physiol. 2012, 160, 145-155. [CrossRef]

46. Lal, M.; Kanwar, H.S.; Kanwar, R.; Lal, C. Effect of planting density and training on plant health and seed quality of bell pepper (Capsicum annuum L.) under protected conditions. J. Appl. Nat. Sci. 2016, 8, 1219-1222. [CrossRef]

47. Vila, M.; Williamson, M.; Lonsdale, M. Competition experiments on alien weeds with crops: Lessons for measuring plant invasion impact? Biol. Invasions 2004, 6, 59-69. [CrossRef]

48. Tracy, B.F.; Sanderson, M.A. Forage productivity, species evenness and weed invasion in pasture communities. Agric. Ecosyst. Environ. 2004, 102, 175-183. [CrossRef]

49. French, R.J.; Smart, W.L.; McCarthy, K. Optimum plant population densities for lupin (Lupinus angustifolius L.) in the Western Australian wheat belt. Aust. J. Exp. Agric. 1994, 34, 491-497. [CrossRef]

(C) 2020 by the authors. Licensee MDPI, Basel, Switzerland. This article is an open access article distributed under the terms and conditions of the Creative Commons Attribution (CC BY) license (http://creativecommons.org/licenses/by/4.0/). 